\title{
A comparative investigation on growth, nanostructure and electrical properties of copper oxide thin films as a function of annealing conditions
}

\author{
K. Khojier $\cdot$ H. Savaloni $\cdot$ Z. Sadeghi
}

Received: 7 December 2013/ Accepted: 7 February 2014/Published online: 27 February 2014

(C) The Author(s) 2014. This article is published with open access at Springerlink.com

\begin{abstract}
This paper is an attempt to compare the influence of various annealing conditions on growth, nanostructure, surface morphology and electrical properties of copper oxide thin films. $\mathrm{Cu}$ thin films of $85 \mathrm{~nm}$ thickness were deposited on glass substrate by thermal evaporation method, and then post-annealed at different environments (air and oxygen flow), different temperatures $\left(200-400{ }^{\circ} \mathrm{C}\right.$ ) and different times (35 and $75 \mathrm{~min}$ ). X-ray diffraction results showed $\left(\mathrm{Cu}_{2} \mathrm{O}\right)$ cuprite phase for all annealed samples at 200 and $250{ }^{\circ} \mathrm{C}$ and $(\mathrm{CuO})$ tenorite phase for all samples annealed under different conditions at 350 and $400{ }^{\circ} \mathrm{C}$. A complex phase of $\mathrm{CuO}$ and $\mathrm{Cu}_{2} \mathrm{O}$ was observed for all annealed samples at $300{ }^{\circ} \mathrm{C}$, with exception for the sample annealed with flow of oxygen for $75 \mathrm{~min}$. The atomic force microscopy results showed that surface morphology of the samples was strongly affected by the changes of annealing conditions (i.e., time, temperature and environment). The size of the grains increased with annealing temperature and time, while the samples annealed with oxygen flow showed larger grains than those annealed in air. Two different behaviors with annealing temperature were distinguished for the surface roughness of the samples annealed in the air and those annealed with
\end{abstract}

K. Khojier $(\square)$

Department of Physics, Chalous Branch, Islamic Azad

University, Chalous, Iran

e-mail: khojier@iauc.ac.ir; k_khojier@yahoo.com

H. Savaloni

Department of Physics, University of Tehran,

North Kargar Street, Tehran, Iran

Z. Sadeghi

Department of Physics, Faculty of Science, Central Tehran

Branch, Islamic Azad University, Tehran, Iran flow of oxygen. Resistivity and Hall effect of samples were measured by a four-point probe instrument and a Hall effect investigation system, respectively. The electrical analyses showed that the variations in annealing conditions had a remarkable effect on measured electrical parameters, namely films resistivity, carriers concentration and type, and Hall mobility.

Keywords Thin film $\cdot$ Copper oxide $\cdot$ Annealing conditions $\cdot$ Nanostructure $\cdot$ Electrical properties

\section{Introduction}

Copper oxide can exist in two crystalline phases viz. cuprous oxide or cuprite $\left(\mathrm{Cu}_{2} \mathrm{O}\right)$ and cupric oxide or tenorite $(\mathrm{CuO})$ [1]. $\mathrm{Cu}_{2} \mathrm{O}$ is a p-type semiconductor of cubic structure with a direct band gap of $2.1-2.6 \mathrm{eV}$, while $\mathrm{CuO}$ is a p-type semiconductor having monoclinic structure and an indirect band gap of 1.9-2.1 eV [2]. However, $\mathrm{CuO}$ is also reported to possess n-type conductivity [3]. Because of their remarkable properties, both of these materials are widely used in photovoltaic devices [4], solar cells [5], magnetic devices [6] and catalysis [7]. $\mathrm{CuO}$ is also used in other various applications, such as gas sensors [5], magnetic storage media [8], solar energy transformation [9], varistors [10].

Many researchers have reported on obtaining copper oxide thin films, using different methods such as sol-gel [11, 12], pulsed magnetron sputtering [13], reactive magnetron sputtering [14], reactive evaporation [15], RF sputtering [16], ion beam sputtering [17], molecular beam epitaxy [18], plasma evaporation [19], and CVD [20], and investigation of various properties of these materials. However, a simple method consisting of deposition of $\mathrm{Cu}$ 
thin film and subsequent annealing may be used to produce copper oxide thin films. Figueiredo et al. [3] and Mohemmed Shanid and Abdul Khadar [1] have separately reported on obtaining the copper oxide thin films by this method. They have produced copper oxide thin films by post-annealing of $\mathrm{Cu}$ thin films at the air environment and investigated different properties of these layers just as a function of annealing temperature. But, nanostructure and different properties of these films can be affected by other annealing conditions. Therefore, we decided to make use of this method and investigate the influence of different annealing conditions (i.e., annealing temperature, time and environment) on crystallographic structure, surface morphology and electrical properties of the produced samples.

\section{Experimental details}

Copper films of $85 \mathrm{~nm}$ thickness were deposited on glass substrates $\left(10 \times 10 \mathrm{~mm}^{2}\right.$ cut from microscope slide $)$ by thermal evaporation from tungsten boat. The purity of the copper was $99.998 \%$. An Edwards (Edwards E19 A3) coating plant was used. Film thickness and deposition rate were measured using a quartz crystal deposition rate controller (Sigma Instruments, SQM- 160, USA) positioned close to the substrate. Deposition angle and deposition rate were $15^{\circ}$ and $3 \AA$, shile base pressure was $2 \times 10^{-5}$ mbar. Post-annealing of the $\mathrm{Cu} / \mathrm{glass}$ films was performed by a horizontal tube furnace at five different temperatures of $200,250,300,350$ and $400{ }^{\circ} \mathrm{C}$ in the air environment and oxygen flow of $200 \mathrm{sccm}$. Two annealing times of 35 and $75 \mathrm{~min}$ were used. The samples reached their target temperature with a thermal gradient of $7 \% \mathrm{~min}$. Prior to deposition, all substrates were ultrasonically cleaned in heated acetone and then ethanol. Crystallographic information of the produced samples was obtained using a Philips XRD X'pert MPD Diffractometer $(\mathrm{Cu} \mathrm{K} \alpha$ radiation) with a step size of $0.02^{\circ}$ and count time of $1 \mathrm{~s}$ per step. Surface morphology and roughness of the samples were obtained by means of AFM (Park Scientific) analysis with a scan rate of $1 \mathrm{~Hz}$ and a scan size of $1 \times 1 \mu \mathrm{m}^{2}$. A four-point probe instrument and a Hall effect system with a magnetic field strength of $0.2 \mathrm{~T}$ were employed for resistivity measurements and Hall effect analysis, respectively.

\section{Results and discussion}

Crystallographic structure

XRD results for all samples are given in Table 1 , and the XRD patterns of selected samples (annealed in the air and oxygen flow for $75 \mathrm{~min}$ ) are shown in Fig. 1. X-ray diffraction pattern of an annealed samples at $200{ }^{\circ} \mathrm{C}$ in the air environment for $35 \mathrm{~min}$ (sample no. $\mathrm{C} 1$ ) showed one peak that can be related to $\mathrm{Cu}_{2} \mathrm{O}(111)$ crystallographic orientation (with reference to JCPDS card no.: 05-667, $2 \theta=36.419^{\circ}$, system: cubic and space group: 224). By increasing the annealing temperature to $250{ }^{\circ} \mathrm{C}$ (sample no. $\mathrm{C} 2)$, the intensity of $\mathrm{Cu}_{2} \mathrm{O}(111)$ peak was increased.

With annealing at $300^{\circ \mathrm{C}}$ (sample no. 3), the intensity of this peak $\left(\mathrm{Cu}_{2} \mathrm{O}(111)\right)$ is decreased, while two other peaks that can be attributed to crystallographic orientations $\mathrm{CuO}(-111)$ and $\mathrm{CuO}(111)$ are appeared (with respect to JCPDS cards no.: 45-0937, $2 \theta=35.496^{\circ}$ and no.: 48-548, $2 \theta=38.709^{\circ}$, system monoclinic and space group: 15$)$. In the XRD pattern of annealed sample at $350{ }^{\circ} \mathrm{C}$ (sample no. C4), the $\mathrm{Cu}_{2} \mathrm{O}(111)$ disappeared and the intensity of $\mathrm{CuO}(-111)$ and $\mathrm{CuO}(111)$ peaks increased. At $400{ }^{\circ} \mathrm{C}$ annealing temperature, the intensities of these two peaks are increased. From these results, it can be deduced that $\mathrm{Cu}_{2} \mathrm{O}$ or cuprous oxide phase is formed at lower annealing temperatures of 200 and $250{ }^{\circ} \mathrm{C}$, while at higher annealing temperatures of 350 and $400{ }^{\circ} \mathrm{C} \mathrm{CuO}$ or cupric oxide phase is formed. A mixture of these two phases (i.e., $\mathrm{Cu}_{2} \mathrm{O}$ and $\mathrm{CuO})$ is presented at annealing temperature of $300{ }^{\circ} \mathrm{C}$. Figueiredo et al. [3] have also reported similar results for their films deposited by electron beam and post-annealed in air for $30 \mathrm{~min}$.

The above-mentioned behavior was observed for almost all samples produced under different conditions, however, with some diversions as follows:

a The intensities of diffraction peaks were higher for those samples annealed at 200, 250, 350 and $400{ }^{\circ} \mathrm{C}$ with flow of oxygen relative to those annealed in air.

b When annealing time increased to $75 \mathrm{~min}$, the diffraction peaks of samples annealed at 200, 250, 350 and $400{ }^{\circ} \mathrm{C}$ showed an increase in the intensity and reduction of the FWHM, indicative of the growth of larger grains (coherently diffracting domains).

c The sample annealed at $300{ }^{\circ} \mathrm{C}$ with flow of oxygen for 75 min (sample no. C18) showed only $\mathrm{CuO}$ phase, while the same sample annealed for shorter time of 35 min showed both $\mathrm{CuO}$ and $\mathrm{Cu}_{2} \mathrm{O}$ phases.

Therefore, it may be concluded that the phase transition of copper oxide films produced in this work is directly related to the annealing temperature, environment and time. On the other hand, a higher presence of oxygen and more annealing time promote an oxidation at lower temperatures. For this reason, there was no $\mathrm{Cu}_{2} \mathrm{O}$ phase in the sample which was sintered at $300{ }^{\circ} \mathrm{C}$ in $\mathrm{O}_{2}$ environment for $75 \mathrm{~min}$.

Crystallite size (coherently diffracting domains) $D$ was obtained by applying the Scherrer formula $(D=k \lambda$ ) $B \cos \theta)$, where $k$ is unity, $\lambda=1.54248 \AA, \theta$ is the peak 
Table 1 Detail of nano-structural results of Cu/glass thin films annealed at different conditions (obtained from XRD and AFM analyses)

\begin{tabular}{|c|c|c|c|c|c|c|c|c|c|}
\hline \multicolumn{4}{|c|}{ Information of samples } & \multicolumn{3}{|l|}{$\mathrm{XRD}$ analysis } & \multicolumn{3}{|c|}{ AFM analysis } \\
\hline \multirow[t]{2}{*}{ No. } & \multirow[t]{2}{*}{$\mathrm{T}\left({ }^{\circ} \mathrm{C}\right) \pm 5$} & \multirow[t]{2}{*}{ Env. } & \multirow[t]{2}{*}{$\begin{array}{l}t(\min ) \\
\pm 1\end{array}$} & \multirow[t]{2}{*}{ Phase } & \multirow[t]{2}{*}{$\begin{array}{l}(\mathrm{hkl}) \\
2 \theta\left({ }^{\circ}\right)\end{array}$} & \multirow[t]{2}{*}{$\begin{array}{l}\text { Intensity (cps) } \\
D(\mathrm{~nm})^{\mathrm{a}}\end{array}$} & \multirow[t]{2}{*}{$\begin{array}{l}D(\mathrm{~nm}) \\
\pm 2\end{array}$} & \multicolumn{2}{|c|}{$\begin{array}{l}\text { Roughness }(\AA) \\
\pm 1\end{array}$} \\
\hline & & & & & & & & $\mathrm{rms}$ & $\mathrm{R}_{\text {ave. }}$ \\
\hline \multirow[t]{2}{*}{$\mathrm{C} 1$} & 200 & Air & 35 & $\mathrm{Cu}_{2} \mathrm{O}$ & (111) & 14 & 19 & 84 & 67 \\
\hline & & & & & 36.43 & 14 & & & \\
\hline \multirow[t]{2}{*}{$\mathrm{C} 2$} & 250 & Air & 35 & $\mathrm{Cu}_{2} \mathrm{O}$ & (111) & 18 & 29 & 72 & 61 \\
\hline & & & & & 36.43 & 22 & & & \\
\hline \multirow[t]{2}{*}{ C3 } & 300 & Air & 35 & $\mathrm{CuO} / \mathrm{Cu}_{2} \mathrm{O} / \mathrm{CuO}$ & $(-111) /(111) /(111)$ & $15 / 13 / 17$ & 61 & 69 & 60 \\
\hline & & & & & $35.51 / 36.45 / 38.71$ & 47 & & & \\
\hline \multirow[t]{2}{*}{$\mathrm{C} 4$} & 350 & Air & 35 & $\mathrm{CuO}$ & $(-111) /(111)$ & $17 / 21$ & 72 & 75 & 66 \\
\hline & & & & & $35.53 / 38.73$ & 49 & & & \\
\hline \multirow[t]{2}{*}{ C5 } & 400 & Air & 35 & $\mathrm{CuO}$ & $(-111) /(111)$ & $19 / 23$ & 75 & 81 & 65 \\
\hline & & & & & $35.51 / 38.73$ & 56 & & & \\
\hline \multirow[t]{2}{*}{ C6 } & 200 & $\mathrm{O}_{2}$ & 35 & $\mathrm{Cu}_{2} \mathrm{O}$ & $(111)$ & 18 & 22 & 73 & 55 \\
\hline & & & & & 36.45 & 16 & & & \\
\hline \multirow[t]{2}{*}{$\mathrm{C} 7$} & 250 & $\mathrm{O}_{2}$ & 35 & $\mathrm{Cu}_{2} \mathrm{O}$ & (111) & 20 & 39 & 82 & 63 \\
\hline & & & & & 36.43 & 28 & & & \\
\hline \multirow[t]{2}{*}{$\mathrm{C} 8$} & 300 & $\mathrm{O}_{2}$ & 35 & $\mathrm{CuO} / \mathrm{Cu}_{2} \mathrm{O} / \mathrm{CuO}$ & $(-111) /(111) /(111)$ & $19 / 13 / 21$ & 70 & 95 & 77 \\
\hline & & & & & $35.51 / 36.46 / 38.73$ & 54 & & & \\
\hline \multirow[t]{2}{*}{ C9 } & 350 & $\mathrm{O}_{2}$ & 35 & $\mathrm{CuO}$ & $(-111) /(111)$ & $21 / 24$ & 78 & 69 & 55 \\
\hline & & & & & $35.51 / 38.71$ & 57 & & & \\
\hline \multirow[t]{2}{*}{$\mathrm{C} 10$} & 400 & $\mathrm{O}_{2}$ & 35 & $\mathrm{CuO}$ & $(-111) /(111)$ & $23 / 27$ & 79 & 66 & 51 \\
\hline & & & & & $35.53 / 38.73$ & 65 & & & \\
\hline \multirow[t]{2}{*}{$\mathrm{C} 11$} & 200 & Air & 75 & $\mathrm{Cu}_{2} \mathrm{O}$ & (111) & 21 & 26 & 114 & 89 \\
\hline & & & & & 36.47 & 20 & & & \\
\hline $\mathrm{C} 12$ & 250 & Air & 75 & $\mathrm{Cu}_{2} \mathrm{O}$ & (111) & 26 & 43 & 103 & 81 \\
\hline & & & & & 36.47 & 39 & & & \\
\hline $\mathrm{C} 13$ & 300 & Air & 75 & $\mathrm{CuO} / \mathrm{Cu}_{2} \mathrm{O} / \mathrm{CuO}$ & $(-111) /(111) /(111)$ & $24 / 14 / 27$ & 92 & 96 & 76 \\
\hline & & & & & $35.53 / 36.45 / 38.73$ & 69 & & & \\
\hline $\mathrm{C} 14$ & 350 & Air & 75 & $\mathrm{CuO}$ & $(-111) /(111)$ & $25 / 28$ & 99 & 104 & 80 \\
\hline & & & & & $35.55 / 38.75$ & 76 & & & \\
\hline $\mathrm{C} 15$ & 400 & Air & 75 & $\mathrm{CuO}$ & $(-111) /(111)$ & $24 / 31$ & 105 & 109 & 84 \\
\hline & & & & & $35.55 / 38.75$ & 82 & & & \\
\hline $\mathrm{C} 16$ & 200 & $\mathrm{O}_{2}$ & 75 & $\mathrm{Cu}_{2} \mathrm{O}$ & (111) & 23 & 35 & 98 & 75 \\
\hline & & & & & 36.47 & 23 & & & \\
\hline $\mathrm{C} 17$ & 250 & $\mathrm{O}_{2}$ & 75 & $\mathrm{Cu}_{2} \mathrm{O}$ & (111) & 28 & 51 & 112 & 91 \\
\hline & & & & & 36.49 & 41 & & & \\
\hline $\mathrm{C} 18$ & 300 & $\mathrm{O}_{2}$ & 75 & $\mathrm{CuO}$ & $(-111) /(111)$ & $26 / 30$ & 100 & 139 & 107 \\
\hline & & & & & $35.55 / 38.75$ & 76 & & & \\
\hline C19 & 350 & $\mathrm{O}_{2}$ & 75 & $\mathrm{CuO}$ & $(-111) /(111)$ & $25 / 31$ & 104 & 102 & 97 \\
\hline & & & & & $35.55 / 38.77$ & 81 & & & \\
\hline $\mathrm{C} 20$ & 400 & $\mathrm{O}_{2}$ & 75 & $\mathrm{CuO}$ & $(-111) /(111)$ & $23 / 37$ & 111 & 93 & 73 \\
\hline & & & & & $35.57 / 38.75$ & 91 & & & \\
\hline
\end{tabular}

$\mathrm{T}$ is the annealing temperature

a Obtained by Scherrer formula for main peaks with higher intensity 
Fig. 1 XRD patterns of annealed $\mathrm{Cu} / \mathrm{glass}$ thin films in: $\mathbf{a}$ air and $\mathbf{b}$ oxygen for $75 \mathrm{~min}$

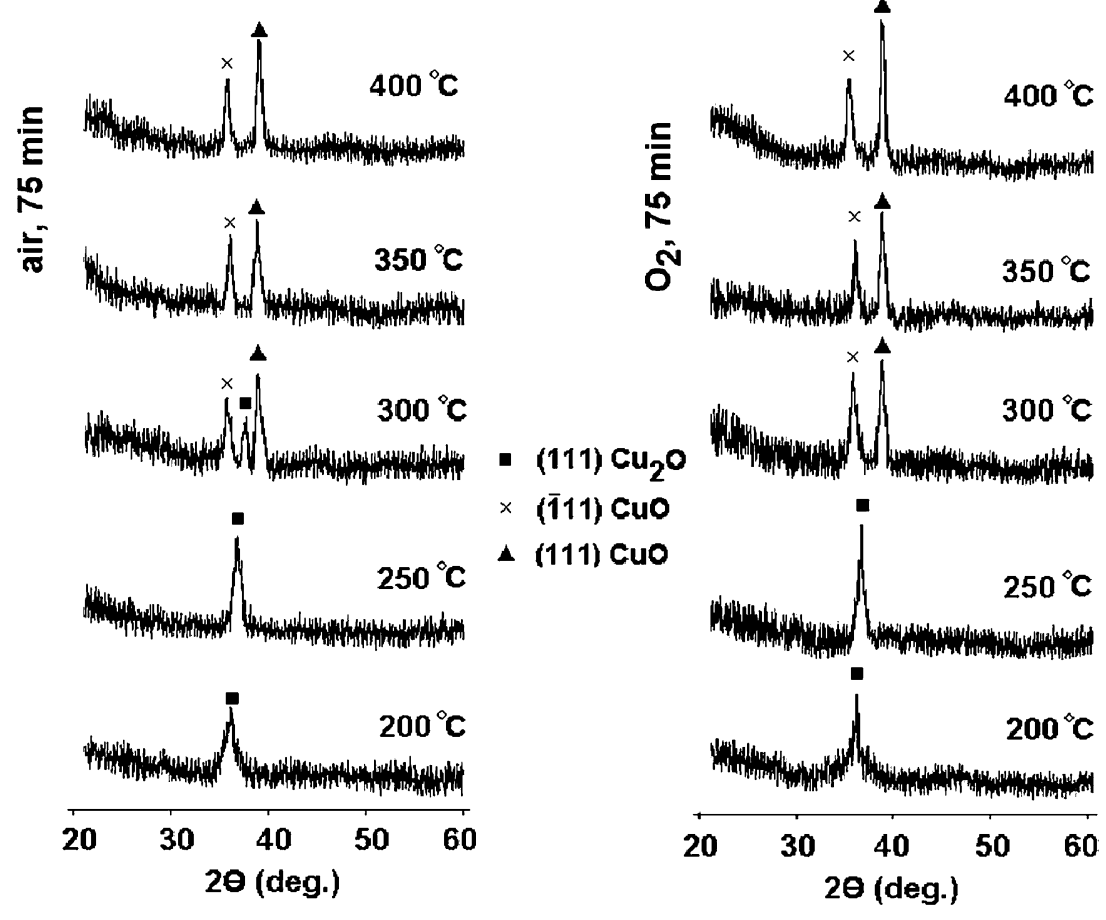

position in radian, and $B$ is calculated from the full width at half maximum of the dominant peak, as $B^{2}=B_{\mathrm{M}}^{2}-B_{\mathrm{s}}^{2}$ ( $B_{\mathrm{M}}$ is FWHM of the sample and $B_{\mathrm{S}}$ is FWHM of the standard sample) [21]. The crystallite size (coherently diffracting domains) results are given in column 7 of Table 1. The results show that grain size increases with annealing temperature, and the films annealed with oxygen flow for longer time have larger grains. The increase in grain size with annealing temperature is clearly due to higher activation energy which causes higher diffusion rate; however, the larger grains obtained for annealing with flow of oxygen relative to those annealed in air can be due to the fact that air apart from oxygen consists of nitrogen and other gases or contaminants that are usually embedded between grains and stop grains from growing larger [22, 23].

\section{Surface morphology}

2D AFM images of selected samples (i.e., samples annealed at $200,300,400{ }^{\circ} \mathrm{C}$ in the air and oxygen flow for $75 \mathrm{~min}$ ) are shown in Fig. 2a-f. Grain sizes of all samples were measured from 2D AFM images using JMicrovision Code. Results are given in column 8 of Table 1 . These results show that the grain size increases with annealing temperature and when samples annealed with flow of oxygen are compared with those annealed in air, it can be observed that the formers contain larger grains.

Figure 3 depicts the 3D AFM images of selected samples, while rms and average roughness of films obtained from AFM analysis are given in columns 9 and 10 of Table 1. These results show that for both annealing environments, namely air and oxygen film, surface roughness increases with annealing time for all annealing temperatures used in this work. This can be due to the fact that at longer annealing time, atoms can move more and fill/ remove the defects of different types (i.e., voids, interstitials and other types), hence larger grains may form as mentioned in column 8 of Table 1 . In addition, by formation of larger grains usually the valleys between the grains become wider and deeper (i.e., grooving effect [24, 25]), hence surface roughness increases. Moreover, two different behaviors can be distinguished for the samples annealed in the air and those annealed with flow of oxygen. The samples annealed in the air show a minimum surface roughness at $300{ }^{\circ} \mathrm{C}$ annealing temperature, while those annealed with flow of oxygen show a maximum value at this temperature.

\section{Concentration of carriers and Hall mobility}

The Hall's effect is important, because it enables us to make measures of mobility and concentration of carriers, and gives insight into the mechanism of conductivity in semiconductors. Figs. 4 and 5 illustrate the variation of carrier concentration and Hall mobility of our samples, respectively. The numerical data and the type of carriers are also given in Table 2. Results (Table 2, column 6) show p-type conductivity for samples with $\mathrm{Cu}_{2} \mathrm{O}$ structure, while samples with $\mathrm{CuO}$ structure have n-type 
Fig. 2 2D AFM images of selected $\mathrm{Cu} /$ glass samples annealed at different temperatures and in different environments for $75 \mathrm{~min}$ : a $200{ }^{\circ} \mathrm{C}$, air; b $300{ }^{\circ} \mathrm{C}$, air; c $400{ }^{\circ} \mathrm{C}$, air; $\mathbf{d} 200{ }^{\circ} \mathrm{C}$, oxygen flow; e $300{ }^{\circ} \mathrm{C}$, oxygen flow; f $400{ }^{\circ} \mathrm{C}$, oxygen flow
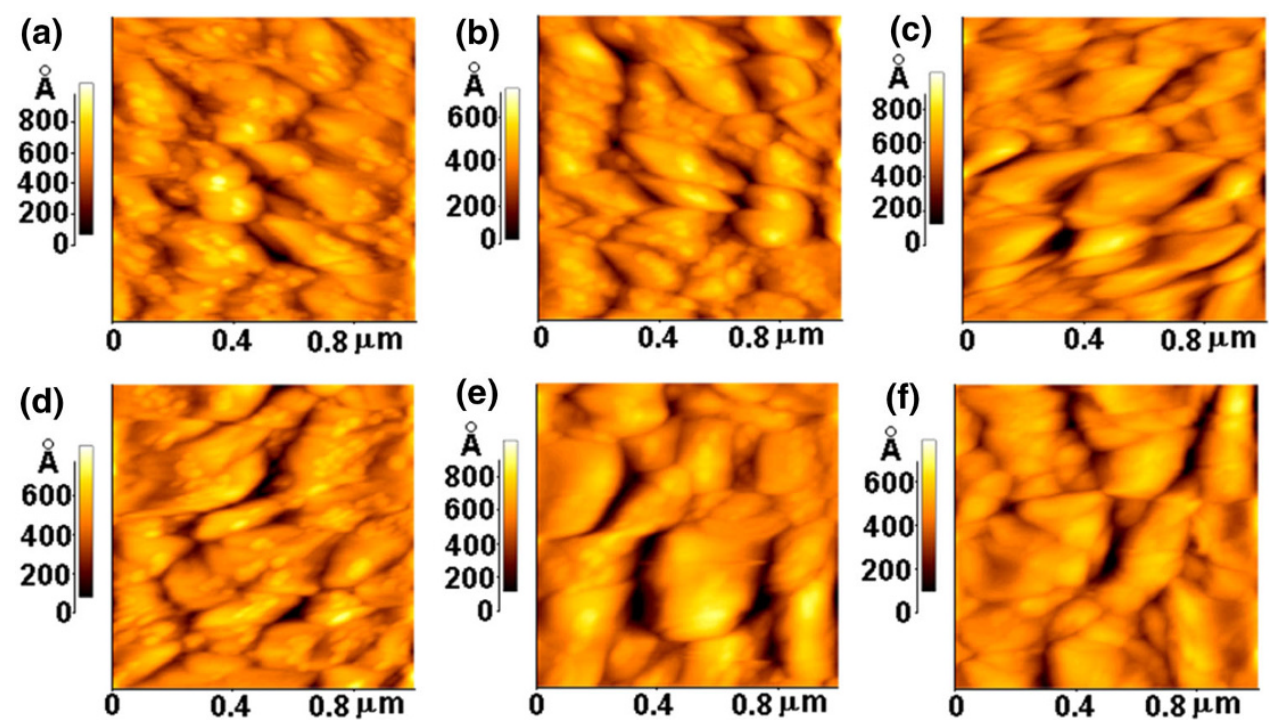

Fig. 3 3D AFM images of selected $\mathrm{Cu} /$ glass samples annealed at different temperatures and in different environments for $75 \mathrm{~min}$ : a $200{ }^{\circ} \mathrm{C}$, air; b $300{ }^{\circ} \mathrm{C}$, air; c $400{ }^{\circ} \mathrm{C}$, air; d $200{ }^{\circ} \mathrm{C}$, oxygen flow; e $300{ }^{\circ} \mathrm{C}$, oxygen flow; f $400{ }^{\circ} \mathrm{C}$, oxygen flow
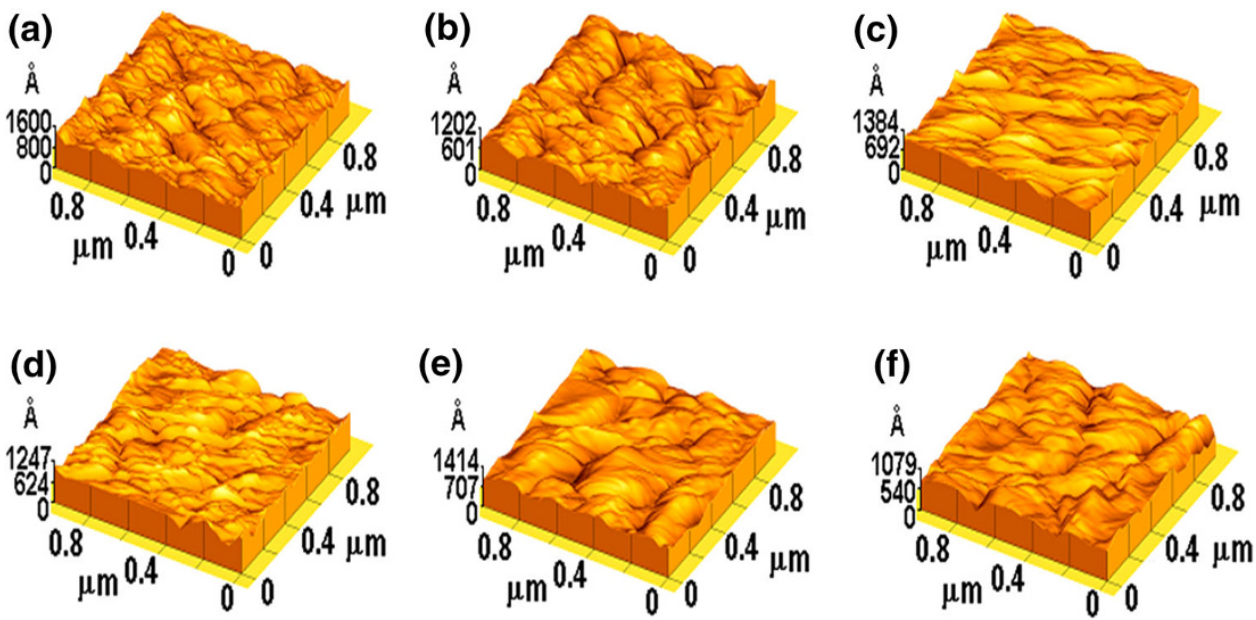

influenced by the film crystallographic structure (phase). Consequently, there exists a correlation between the results obtained for carrier concentration, Hall mobility and the crystallographic structure (phase) of the samples produced in this work.

\section{Resistivity}

Results of DC resistivity measurement obtained using a four-point probe instrument is discussed in this section. To investigate the influence of possible (low frequency) charging effects at the electrical contacts and leads, current-voltage $(I-V)$ curves were recorded in both increasing and decreasing increments of voltage. The results of the measurements in the decreasing direction of the voltage are not shown as they matched the results in the increasing voltage direction and only clutter the figure unnecessarily. Linear $I-V$ curves were obtained for all samples; independent of the scan direction, there was no indication of concentration as discussed above, hence are directly 


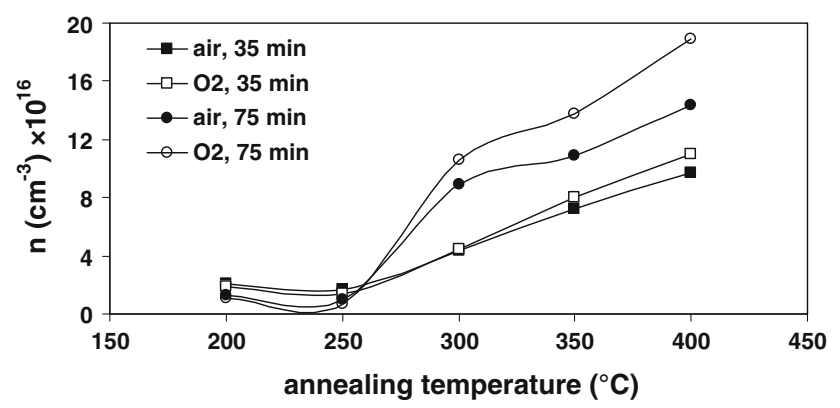

Fig. 4 Variation in carrier concentration of the samples produced at different annealing times and in different environments as a function of annealing temperature (the lines are guides to the eyes)

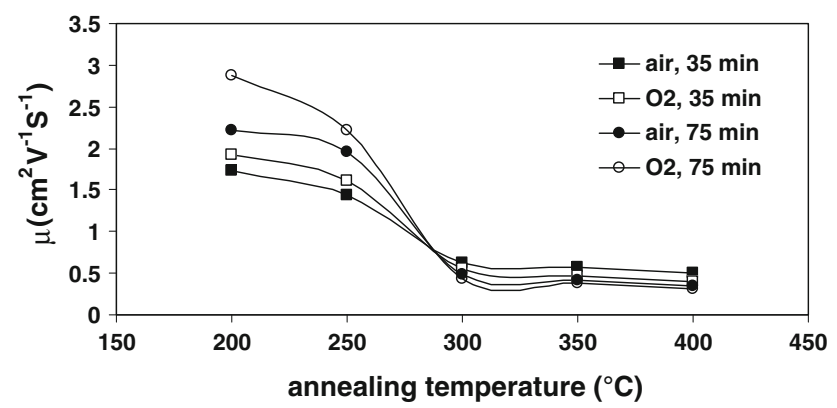

Fig. 5 Variation in Hall mobility of the samples produced at different annealing times and in different environments as a function of annealing temperature (the lines are guides to the eyes) hysteresis effect. To investigate the anisotropy effect in these samples, the $I-V$ curve measurements were also carried out in four different directions on the samples, namely two vertical (along the sample length and normal to the length) and two diagonal directions. Figure 6 depicts the results of $I-V$ curves for selected samples that were heated in air for $35 \mathrm{~min}$ as a function of annealing temperature, while the values of average resistivity for all samples measured at room temperature are given in column 5 of Table 2 and Fig. 7. The results show that resistivity increases with annealing temperature up to $300{ }^{\circ} \mathrm{C}$ and decreases at higher annealing temperatures. The variation of the resistivity of our samples again regardless of their annealing environment and annealing time shows a peak value for the samples annealed at $300{ }^{\circ} \mathrm{C}$. Consulting the crystallographic structure (Table 1, column 5) and carrier type (Table 2, column 6) indicates that at this temperature the samples contain a mixture of two phases with two different types of carriers, namely $\mathrm{Cu}_{2} \mathrm{O}$ (p-type) and $\mathrm{CuO}$ (n-type), though the final identification in Table 2 for the carrier type of these samples is given as p-type. The increased resistivity of these samples could be due to existence of these two different types of carriers in these samples that act in two different directions.

A similar variation of resistivity for films produced by e-beam deposition and subsequent annealing in air for $30 \mathrm{~min}$ is reported by Figueiredo et al. [3].
Table 2 Electrical properties results of $\mathrm{Cu} /$ glass thin films annealed at different conditions (measured by four-point probe instrument and Hall effect investigation system)

$\mathrm{T}$ is the annealing temperature

\begin{tabular}{llllllll}
\hline No. & $T\left({ }^{\circ} \mathrm{C}\right) \pm 5$ & Env. & $t(\mathrm{~min}) \pm 1$ & $\rho(\Omega \mathrm{cm})$ & Carriers type & $n\left(\mathrm{~cm}^{-3}\right) \times 10^{16}$ & $\mu\left(\mathrm{cm}^{2} \mathrm{~V}^{-1} \mathrm{~S}^{-1}\right)$ \\
\hline $\mathrm{C} 1$ & 200 & Air & 35 & $104.0 \pm 4$ & $\mathrm{p}$ & $2.1 \pm 0.08$ & $1.73 \pm 0.06$ \\
$\mathrm{C} 2$ & 250 & Air & 35 & $225.3 \pm 9$ & $\mathrm{p}$ & $1.7 \pm 0.06$ & $1.43 \pm 0.05$ \\
$\mathrm{C} 3$ & 300 & Air & 35 & $425.6 \pm 17$ & $\mathrm{p}$ & $4.4 \pm 0.16$ & $0.62 \pm 0.02$ \\
$\mathrm{C} 4$ & 350 & Air & 35 & $311.3 \pm 12$ & $\mathrm{n}$ & $7.2 \pm 0.28$ & $0.57 \pm 0.02$ \\
$\mathrm{C} 5$ & 400 & Air & 35 & $138.7 \pm 5$ & $\mathrm{n}$ & $9.7 \pm 0.36$ & $0.51 \pm 0.02$ \\
$\mathrm{C} 6$ & 200 & $\mathrm{O}_{2}$ & 35 & $122.4 \pm 4$ & $\mathrm{p}$ & $1.9 \pm 0.07$ & $1.93 \pm 0.07$ \\
$\mathrm{C} 7$ & 250 & $\mathrm{O}_{2}$ & 35 & $241.8 \pm 10$ & $\mathrm{p}$ & $1.4 \pm 0.05$ & $1.61 \pm 0.06$ \\
$\mathrm{C} 8$ & 300 & $\mathrm{O}_{2}$ & 35 & $485.4 \pm 17$ & $\mathrm{p}$ & $4.5 \pm 0.17$ & $0.56 \pm 0.02$ \\
$\mathrm{C} 9$ & 350 & $\mathrm{O}_{2}$ & 35 & $301.9 \pm 12$ & $\mathrm{n}$ & $7.4 \pm 0.30$ & $0.47 \pm 0.02$ \\
$\mathrm{C} 10$ & 400 & $\mathrm{O}_{2}$ & 35 & $126.9 \pm 5$ & $\mathrm{n}$ & $10.1 \pm 0.44$ & $0.40 \pm 0.02$ \\
$\mathrm{C} 11$ & 200 & Air & 75 & $145.3 \pm 5$ & $\mathrm{p}$ & $1.3 \pm 0.05$ & $2.21 \pm 0.08$ \\
$\mathrm{C} 12$ & 250 & Air & 75 & $275.2 \pm 9$ & $\mathrm{p}$ & $1.0 \pm 0.04$ & $1.96 \pm 0.07$ \\
$\mathrm{C} 13$ & 300 & Air & 75 & $519.1 \pm 20$ & $\mathrm{p}$ & $8.9 \pm 0.32$ & $0.49 \pm 0.02$ \\
$\mathrm{C} 14$ & 350 & Air & 75 & $294.4 \pm 12$ & $\mathrm{n}$ & $10.9 \pm 0.50$ & $0.42 \pm 0.02$ \\
$\mathrm{C} 15$ & 400 & Air & 75 & $112.8 \pm 4$ & $\mathrm{n}$ & $14.4 \pm 0.56$ & $0.35 \pm 0.01$ \\
$\mathrm{C} 16$ & 200 & $\mathrm{O}_{2}$ & 75 & $183.6 \pm 5$ & $\mathrm{p}$ & $1.1 \pm 0.04$ & $2.87 \pm 0.11$ \\
$\mathrm{C} 17$ & 250 & $\mathrm{O}_{2}$ & 75 & $310.9 \pm 12$ & $\mathrm{p}$ & $0.7 \pm 0.28$ & $2.22 \pm 0.08$ \\
$\mathrm{C} 18$ & 300 & $\mathrm{O}_{2}$ & 75 & $504.1 \pm 20$ & $\mathrm{n}$ & $10.6 \pm 0.40$ & $0.43 \pm 0.02$ \\
$\mathrm{C} 19$ & 350 & $\mathrm{O}_{2}$ & 75 & $291.6 \pm 11$ & $\mathrm{n}$ & $12.4 \pm 0.50$ & $0.38 \pm 0.01$ \\
$\mathrm{C} 20$ & 400 & $\mathrm{O}_{2}$ & 75 & $103.1 \pm 4$ & $\mathrm{n}$ & $18.9 \pm 0.72$ & $0.31 \pm 0.01$ \\
\hline
\end{tabular}




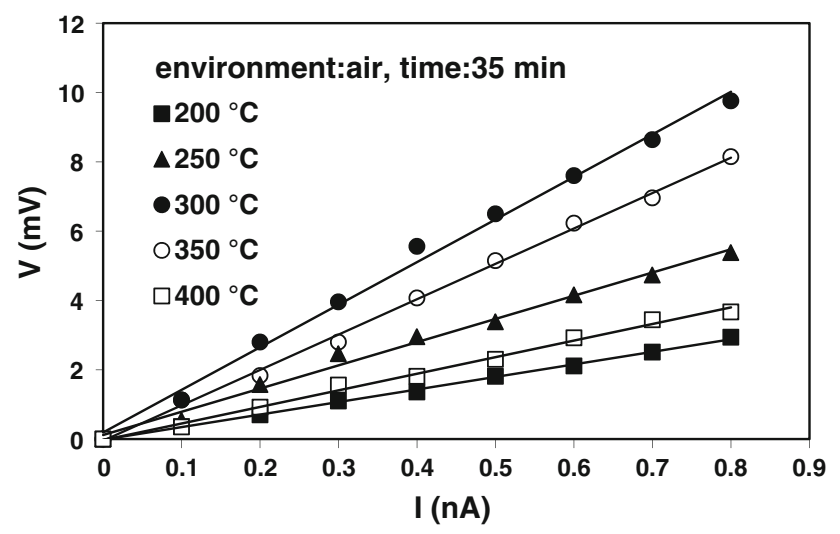

Fig. $6 I-V$ curves for $\mathrm{Cu} /$ glass thin films annealed in air for $35 \mathrm{~min}$

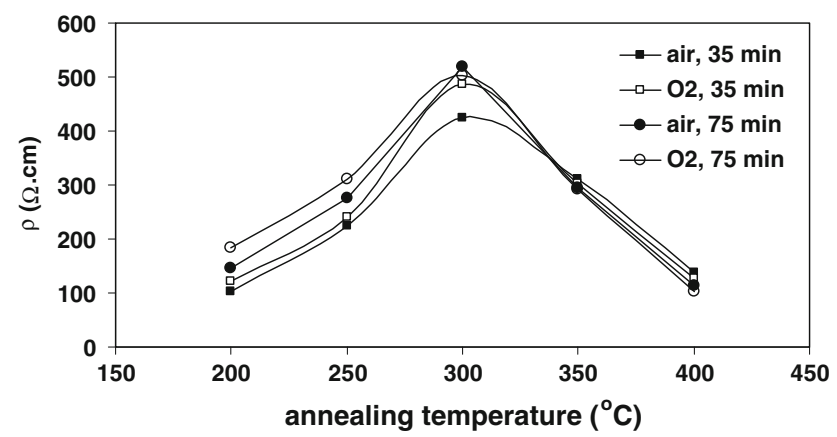

Fig. 7 Variation in resistivity of $\mathrm{Cu}$ /glass thin films annealed at different times and in different environments as a function of annealing temperature (the lines are guides to the eyes)

\section{Conclusion}

$\mathrm{Cu}$ thin films of $85 \mathrm{~nm}$ thickness were produced by thermal evaporation on glass substrates. The samples were postannealed at different temperatures $\left(200-400{ }^{\circ} \mathrm{C}\right)$, different environments (air and flow of oxygen) and different annealing times (35 and $75 \mathrm{~min}$ ). Crystallographic and morphological investigations were carried out using XRD and AFM analyses, respectively. Resistivity and Hall mobility and carrier concentration of samples were obtained by means of four-point probe and Hall effect investigation instrument separately. Two different phases of copper oxide films, namely $\mathrm{Cu}_{2} \mathrm{O}$ and $\mathrm{CuO}$, were observed at lower temperatures (up to $250{ }^{\circ} \mathrm{C}$ ) and higher temperatures $\left(350\right.$ and $400{ }^{\circ} \mathrm{C}$ ) for all samples, respectively, while at the transition annealing temperature of $300{ }^{\circ} \mathrm{C}$ a mixture of both of these phases was obtained for all samples except that annealed with flow of oxygen and for $75 \mathrm{~min}$. Grain sizes obtained from AFM images indicated that the grain size increased with annealing temperature and annealing time, while those annealed with flow of oxygen produced larger grains than those processed in air. Samples annealed in the air showed a minimum surface roughness at $300{ }^{\circ} \mathrm{C}$ annealing temperature, while those annealed with flow of oxygen showed a maximum surface roughness at this annealing temperature. This phenomenon may be related to the crystallographic structure of these films, so that those annealed at this certain temperature and in air contain both $\mathrm{CuO}$ and $\mathrm{Cu}_{2} \mathrm{O}$ grains, whereas those annealed in the oxygen flow (at $300{ }^{\circ} \mathrm{C}$ ) contain only $\mathrm{CuO}$ grains (particularly at increased annealing time of $75 \mathrm{~min}$ ) or much less amount of $\mathrm{Cu}_{2} \mathrm{O}$ (35 min annealing time). This can also be deduced from the ratio of intensities of the peaks of $\mathrm{Cu}_{2} \mathrm{O}$ to $\mathrm{CuO}$ for these samples (Table 1, column 7), hence distribution of smaller grains (lower intensities of three peaks in the XRD pattern) causes almost a uniform surface (minimum surface roughness) while large grains (higher intensities of two peaks in the XRD pattern) produce a rough surface. In fact, our discussion emphasis is on the distribution of smaller $\mathrm{Cu}_{2} \mathrm{O}$ grains among the $\mathrm{CuO}$ grains. The electrical results showed n-type conductivity for $\mathrm{CuO}$ phase and p-type conductivity for $\mathrm{Cu}_{2} \mathrm{O}$ phase. The variations in the resistivity, concentration of carriers and Hall mobility showed a direct correlation with the crystallographic phase changes of the samples as a function of annealing temperature regardless of annealing time and annealing environment.

Acknowledgments This work was carried out with the support of the Islamic Azad University, Chalous branch and central Tehran branch. H.S. is grateful to the University of Tehran for partial support of this work. The authors are also grateful to Mrs. R. Akbarpour.

Conflict of interest The authors declare that they have no competing interests.

Author contribution All authors provided the same contributions in this article. All authors read and approved the final manuscript.

Open Access This article is distributed under the terms of the Creative Commons Attribution License which permits any use, distribution, and reproduction in any medium, provided the original author(s) and the source are credited.

\section{References}

1. Mohemmed Shanid, N.A., Abdul Khadar, M.: Evolution of nanostructure, phase transition and band gap tailoring in oxidized $\mathrm{Cu}$ thin films. Thin Solid Films 516, 6245-6252 (2008)

2. Ray, S.C.: Preparation of copper oxide thin film by the sol-gellike dip technique and study of their structural and optical properties. Sol. Energy Mater. Sol. Cells 68, 307-312 (2001)

3. Figueiredo, V., Elangovan, E., Goncalves, G., Barquinha, P., Pereira, L., Franco, N., Alves, E., Martins, R., Fortunato, E.: Effect of post-annealing on the properties of copper oxide thin films obtained from the oxidation of evaporated metallic copper. Appl. Surf. Sci. 254, 3949-3954 (2008)

4. Koffyberg, F.P., Benko, F.A.: A photoelectrochemical determination of the position of the conduction and valence band edges of p-type CuO. J. Appl. Phys. 53, 1173-1175 (1982)

5. Serin, N., Serin, T., Horzum, S., Celik, Y.: Annealing effects on the properties of copper oxide thin films prepared by chemical deposition. Semicond. Sci. Technol. 20, 398-401 (2005) 
6. Gan, Z.H., Yu, G.Q., Tay, B.K., Tan, C.M., Zhao, Z.W., Fu, Y.Q.: Preparation and characterization of copper oxide thin films deposited by filtered cathodic vacuum arc. J. Phys. D Appl. Phys. 37, 81-85 (2005)

7. Kari Brown, E.R., Choi, K.: Synthesis and characterization of transparent nanocrystalline $\mathrm{Cu}_{2} \mathrm{O}$ films and their conversion to $\mathrm{CuO}$ films. Chem. Commun. 31, 3311-3313 (2006)

8. Borzi, R.A., Stewart, S.J., Mercader, R.C., Punte, G., Garcia, F.: Magnetic behavior of nanosized cupric oxide. J. Magn. Magn. Mater. 226-230, 1513-1515 (2001)

9. Balamurugan, B., Mehta, B.R., Avasthi, D.K., Singh, F., Arora, A.K., Rajalakshmi, M., Raghavan, G., Tyagi, A.K., Sivaprasad, S.M.: Modifying the nanocrystalline characteristics-structure, size, and surface states of copper oxide thin films by high-energy heavy-ion irradiation. J. Appl. Phys. 92, 3304-3310 (2002)

10. Wang, W., Liu, Z., Liu, Y., Xu, C., Zheng, C., Wang, G.: A simple wet-chemical synthesis and characterization of $\mathrm{CuO}$ nanorods. Appl. Phys. A 76, 417-420 (2003)

11. Nair, M.T.S., Guerrero, L., Arenas, O.L., Nair, P.K.: Chemically deposited copper oxide thin films: structural, optical and electrical characteristics. Appl. Surf. Sci. 150, 143-151 (1999)

12. Oral, A.Y., Mensur, E., Aslan, M.H., Basaran, E.: The preparation of copper(II) oxide thin films and the study of their microstructures and optical properties. Mater. Chem. Phys. 83, 140-144 (2004)

13. Alkoy, E.M., Kelly, P.J.: The structure and properties of copper oxide and copper aluminium oxide coatings prepared by pulsed magnetron sputtering of powder targets. Vacuum 79, 221-230 (2005)

14. Pierson, J.F., Thobor-Keck, A., Billard, A.: Cuprite, paramelaconite and tenorite films deposited by reactive magnetron sputtering. Appl. Surf. Sci. 210, 359-367 (2003)

15. Balamurugan, B., Mehta, B.R.: Optical and structural properties of nanocrystalline copper oxide thin films prepared by activated reactive evaporation. Thin Solid Films 396, 90-96 (2001)
16. Ghosh, S., Avasthi, D.K., Shah, P., Ganesan, V., Gupta, A., Sarangi, D., Bhattacharya, R., Assmann, W.: Deposition of thin films of different oxides of copper by RF reactive sputtering and their characterization. Vacuum 57, 377-385 (2000)

17. Yoon, K.H., Choi, W.J., Kang, D.H.: Photoelectrochemical properties of copper oxide thin films coated on an $n$-Si substrate. Thin Solid Films 372, 250-256 (2000)

18. Muthe, K.P., Vyas, J.C., Narang, S.N., Aswal, D.K., Gupta, S.K., Bhattacharya, D., Pinto, R., Kothiyal, G.P., Sabharwal, S.C.: A study of the $\mathrm{CuO}$ phase formation during thin film deposition by molecular beam epitaxy. Thin Solid Films 324, 37-43 (1998)

19. Santra, K., Sarker, C.K., Mukherjee, M.K., Ghosh, B.: Copper oxide thin films grown by plasma evaporation method. Thin Solid Films 213, 226-229 (1992)

20. Maruyama, T.: Copper oxide thin films prepared by chemical vapor deposition from copper dipivaloylmethanate. Sol. Energy Mater. Sol. Cells 56, 85-92 (1998)

21. Warren, B.E.: X-ray Diffraction. Addison Wesley Publishing Co., London (1969)

22. Savaloni, H., Player, M.A., Gu, E., Marr, G.: Influence of substrate temperature, deposition rate, surface texture and material on the structure of uhv deposited erbium films. Vacuum $\mathbf{4 3}$, 965-980 (1992)

23. vander Kolk, G.J., Verkerk, M.J.: Microstructural studies of the growth of aluminum films with water contamination. J. Appl. Phys. 59, 4062-4067 (1986)

24. Khojier, K., Savaloni, H., Kangarloo, H., Ghorannneviss, M., Yari, M.: Influence of annealing temperature on the nanostructure and corrosivity of Ti/stainless steel substrates. Appl. Surf. Sci. 254, 2528-2533 (2008)

25. Aspnes, D.E., Kinsbron, E., Bacon, D.D.: Optical properties of Au: sample effects. Phys Rev. B 21, 3290-3299 (1980) 